\title{
ORGANIC EVAPORATOR STEAM VALVE FAILURE (U)
}

by R. A. Jacobs

Westinghouse Savannah River Company

Savannah River Site

Aiken, South Carolina 29808

Other Authors:
WSRC-RP--92-1178

DE93 011775

This paper was prepared in connection with work done under Contract No. DE-AC09-89SR18035 with the U.S. Department of Energy. By acceptance of this paper, the publisher and/or recipient acknowledges thie U.S. Government's right to retain a nonexclusive, royalty-free license in and to any copyright covering this paper, along with the right to reproduce and to authorize others to reproduce all or part of the copyrighted paper. 


\section{DISCLAIMER}

This report was prepared as an account of work sponsored by an agency of the United States Government. Neither the United States Government nor any agency thereof, nor any of their employees, makes any warranty, express or implied, or assumes any legal liability or responsibility for the accuracy, completeness, or usefulness of any information, apparatus, product, or process disclosed, or represents that its use would not infringe privately owned rights. Reference herein to any specific commercial product, process, or service by trade name, trademark, manufacturer, or otherwise does not necessarily constitute or imply its endorsement, recommendation, or favoring by the United States Government or any agency thereof. The views and opinions of authors expressed herein do not necessarily state or reflect those of the United States Government or any agency thereof.

This report has been reproduced directly from the best available copy.

Available to DOE and DOE contractors from the Office of Scientific and Technical Information, P.O. Box 62, Oak Ridge, TN 37831; prices available from (615) 576-8401, FTS 626-8401.

Available to the public from the National Technical Information Service, U.S. Department of Commerce, 5285 Port Royal Rd., Springfield, VA 22161. 


\title{
INTER-OFFICE MEMORANDUM
}

\author{
WSRC-RP-92-1178 \\ Keywords: DWPE, Organic \\ Evaporator, Salt Process \\ Cell, PVVS
}

Retention period: Permanent

cc: J. T. Carter, 704-1T

L. F. Landon, 704-T

D. P. Lambert, 704-1T

SRI Records (4)*

September 29,1992

TO: E. W. HOLTZSCHEITER, 773-A

ERoM: R. A. JACOBS, 704-T $\mathrm{Al}$ facales

ORGANIC MYAPOBATOR STHAK YATYE FATIURF (U)

\section{Suminary and conclusions}

DWPE Technical has requested an analysis of the capacity of the Organic Evaporator (OE) condenser (OEC) be performed to determine its capability in the case where the $O E$ steam flow control valve fails open. Calculations of the OE boilup and the OEC heat transfer coefficient indicate the OEC will have more than enough capacity to remove the heat at maximum OE boilup. In fact, the Salt Cell Vent Condenser (SCVC) should also have sufficient capacity to handle the maximum oE boilup. Therefore, it would require simultaneous loss of OEC and/or SCVC condensing capacity for the steam valve failure to cause high benzene in the process Vessel Vent System (PVVS).

\section{Discussion}

\section{Background}

One of the scenarios included in the Salt Process Cell (SPC) fault tree analysis is failure of the Organic Evaporator steam valve in the open position with benzene in the OE. This occurrence ispostulated to result in a flammable benzene

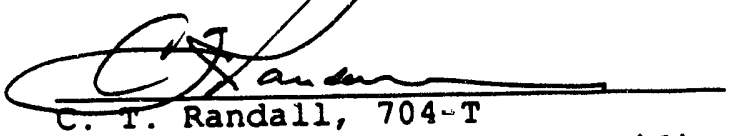

Authorized Derivative Classifier 
concentration in the PVVS by overwhelming the capability of the condensers (both OEC and SCVC) to condense the benzene boiled up. The purpose of the following calculations is to show that other simultaneous failures are required for the postulated scenario to occur.

\section{Calculations}

\section{Assumptions and Notes}

- Assumed cooling water supply temperature is $35^{\circ} \mathrm{C}$

- Bolling and condensing is assumed to occur at the aqueous boiling temperature observed in the Precipitate Hydrolysis Experimental Facility (PHEF) operating experience indicates this is $72-74^{\circ} \mathrm{C} ; 72^{\circ} \mathrm{C}$ is used for this analysis.

- Inert flow during this scenario is low, especially compared to the maximum benzene boilup rate. Therefore, nearly all condensation occurs at the boiling temperature; that is, it is reasonable to assume constant temperature condensation.

- Heat transfer coefficients (U'S) are from PHEF OE operation and are consistent with similar values for the Precipitate Reactor.

- Other data (areas, flow rates, pressures, etc) were provided by DWPF personnel.

$1 \mathrm{PCU}=1.8 \mathrm{Btu}$

Maximum OE Boilup

Maximum boilup is determined by assuming that heat transfer is limited by the heat transfer coefficient; that is, steam can be supplied at sufficient rate to maintain the steam coil at the 85 psig steam supply pressure (maximum steam condensing temperature).

$$
\begin{aligned}
& + \text { Temperature of } 85 \mathrm{psig} \text { steam }=164^{\circ} \mathrm{C} \\
& + \text { OE steam Coil area }=51 \mathrm{ft}^{2} \\
& +U \text { OE steam COIl }=200 \frac{\mathrm{PCU}}{\mathrm{hr}-\mathrm{ft}^{2}-{ }^{\circ} \mathrm{C}} \\
& + \text { Qstm }=\mathrm{UA \Delta T}=200 \frac{\mathrm{PCU}}{\mathrm{hr}-\mathrm{ft}^{2}-{ }^{\circ} \mathrm{C}} \star 51 \mathrm{ft}^{2} \star \\
& (164-72)^{\circ} \mathrm{C}=938400 \frac{\mathrm{PCU}}{\mathrm{hr}}
\end{aligned}
$$

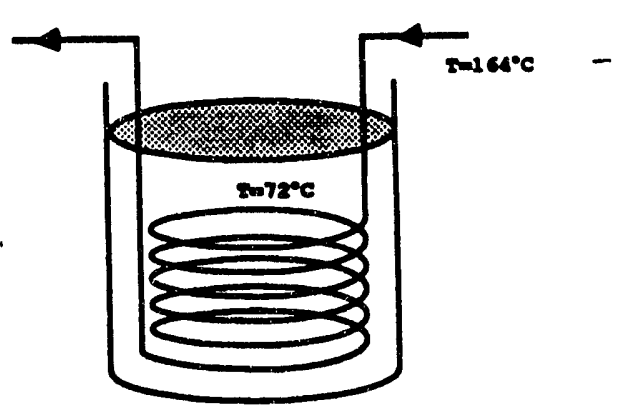

For steam with $\Delta \mathrm{H}_{\mathrm{vap}}=494 \mathrm{PCU} / \mathrm{lb}$, this is equivalent to $\sim 1900$ lbs/hr steam.

Heat Removed by OE cooling coil 
E. W. HOLTZSCHEITER

If an interlock puts cooling water (CW) on the OE cooling coil,

it will remove some of the heat provided by the steam.

$+\mathrm{CW}$ supply temperature $=35^{\circ} \mathrm{C}$

$+C W$ supply flow $=100 \mathrm{gpm}$

+ OE cooling coil area $=15 \mathrm{ft}^{2}$

$+U$ OE cooling $\operatorname{coil}=250 \frac{\mathrm{PCU}}{\mathrm{hr}-\mathrm{ft} \mathrm{t}^{2}-{ }^{\circ} \mathrm{C}}$

$+\Delta t_{C W}=\frac{(72-35)+\left(72-t_{e}\right)}{2}=54.5-0.5 t_{e}$

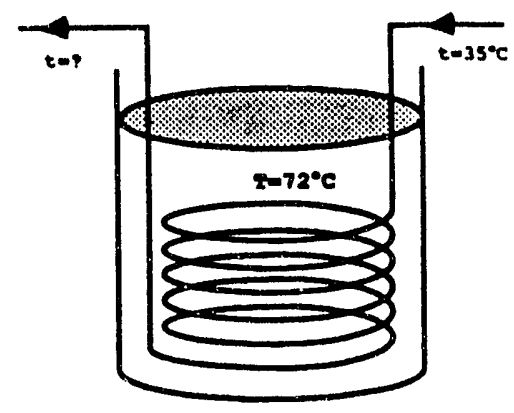

$+Q_{c l n g}$ coil $=m C_{p} \Delta t_{c W}=U A \Delta T$,

substituting gives

$$
\begin{aligned}
& 100 \frac{\mathrm{gal}}{\mathrm{min}} \star 500 \frac{\mathrm{lbs} / \mathrm{hr}}{\mathrm{gal} / \mathrm{min}} * 1 \frac{\mathrm{PCU}}{\mathrm{hr}-\mathrm{ft} \mathrm{C}^{2}-{ }^{\circ} \mathrm{C}} \star\left(t_{e}-35\right)^{\circ} \mathrm{C}= \\
& 15 f t^{2} \star 250 \frac{\mathrm{PCU}}{\mathrm{hr}-\mathrm{ft} \mathrm{t}^{2}-{ }^{\circ} \mathrm{C}} \star\left(54.5-0.5 t_{\mathrm{e}}\right){ }^{\circ} \mathrm{C} \\
& t_{e}=37.7^{\circ} \mathrm{C} \Rightarrow \Delta t_{C W}=2.7^{\circ} \mathrm{C} \\
& +Q_{c l n g} \text { coil }=100 \frac{\mathrm{gal}}{\mathrm{min}} * 500 \frac{\mathrm{lbs} / \mathrm{hr}}{\mathrm{gal} / \mathrm{min}} * 1 \frac{\mathrm{PCU}}{\mathrm{hr}-\mathrm{ft}^{2}-{ }^{\circ} \mathrm{C}} *(2.7)^{\circ} \mathrm{C}= \\
& =135000 \frac{\mathrm{PCU}}{\mathrm{hr}} \Rightarrow \text { QOEC }=803400 \frac{\mathrm{PCU}}{\mathrm{hr}}
\end{aligned}
$$

For $\Delta H_{\text {vap }}$ of benzene $=94 \mathrm{PCU} / 1 \mathrm{~b}$, the benzene boilup rate is $\sim$ $8550 \mathrm{lbs} / \mathrm{hr}$. 
Required $U$ for $O E C$

Given the heat load, determine the required heat transfer coefficient and compare to expected values and/or experience.

$$
\begin{aligned}
& +\mathrm{CW} \text { supply temperature }=35^{\circ} \mathrm{C} \\
& +C W \text { supply flow }=150 \mathrm{gpm} \\
& + \text { OEC area }=576 \mathrm{ft}^{2} \\
& +\Delta t_{C W}=\frac{\Omega}{m_{C p}}= \\
& \frac{803400 \frac{\mathrm{PCU}}{\mathrm{hr}}}{150 \frac{\mathrm{gal}}{\mathrm{min}} * 500 \frac{\mathrm{lbs} / \mathrm{hr}}{\mathrm{gal} / \mathrm{min}} * 1 \frac{\mathrm{PCU}}{\mathrm{hr}-\mathrm{ft}{ }^{2}-{ }^{\circ} \mathrm{C}}}
\end{aligned}
$$

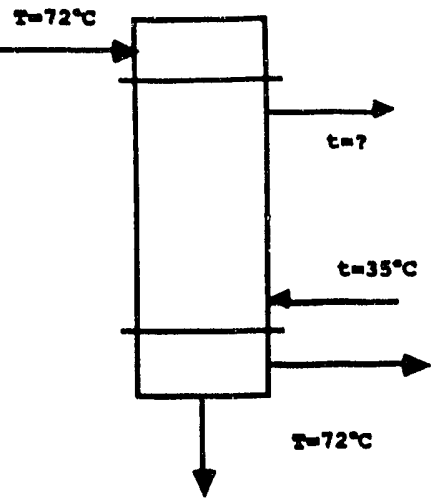

$$
\begin{aligned}
& =10.7^{\circ} \mathrm{C} \\
& \Rightarrow t_{e}=45.7^{\circ} \mathrm{C} \\
& +\Delta T_{1 m}=\frac{(72-35)-(72-45.7)}{\ln \frac{72-35}{72-45.7}}=31.35^{\circ} \mathrm{C} \\
& +U_{\text {OEC reqd }}=\frac{Q}{A \Delta \mathrm{T}_{1 \mathrm{~m}}}=\frac{803400 \frac{\mathrm{PCU}}{\mathrm{hr}}}{576 \mathrm{ft}^{2} \star 31.35^{\circ} \mathrm{C}}=44.5 \frac{\mathrm{PCU}}{\mathrm{hr}-\mathrm{ft}^{2}-{ }^{\circ} \mathrm{C}}
\end{aligned}
$$

This heat transfer coefficient is low for condensing; it would be expected to be several times higher. Typical values (Table 7-1, Basic Heat Transfer, Kreith \& Black) are $175-700 \mathrm{PCU} / \mathrm{hr}-\mathrm{ft}^{2}-^{\circ} \mathrm{C}$ for steam/water (tube side/shell side) condensation and 50-175 $\mathrm{PCU} / \mathrm{hr}-\mathrm{ft}^{2}-{ }^{\circ} \mathrm{C}$ for organic vapor/water condensation. For organic vapors, the higher values are for lighter, lower-boiling, thinner organics while the lower values are for heavier, higher-boiling, thicker materials (benzene fails in the former category). U's of 80 or so have been measured in PHEF at aqueous boiling but the condensers do not have sufficient load on them to use all the area for heat transfer; therefore the calculated U's (which use the total heat exchanger area) would be low.

OEC without $O E$ cooling coil

This is the same as the previous calculation except $Q=$ $938400 \mathrm{PCU} / \mathrm{hr}$. 
E. W. HOLTZSCHEITER

$$
\begin{aligned}
+\Delta t_{C W} & =\frac{Q}{m_{\mathrm{p}}}=\frac{938400}{150 \star 500 \star 1}=12.5^{\circ} \mathrm{C} \\
& \Rightarrow t_{e}=47.5^{\circ} \mathrm{C} \\
+\Delta \mathrm{T}_{1 \mathrm{~m}} & =\frac{(72-35)-(72-47.5)}{\ln \frac{72-35}{72-47.5}}=30.32^{\circ} \mathrm{C} \\
+\mathrm{U}_{\text {OEC }} \text { reqd } & =\frac{Q}{\mathrm{~A} \Delta \mathrm{T}_{1 \mathrm{~m}}}=\frac{938400}{576 \star 30.32}=53.7 \frac{\mathrm{PCU}}{\mathrm{hr}-\mathrm{ft}^{2}-{ }^{\circ} \mathrm{C}}
\end{aligned}
$$

SCVC without OEC Or OE cooling coil

This is the same analysis except that

$+\mathrm{CW}$ supply temperature $=10^{\circ} \mathrm{C}$

$+C W$ supply flow $=100 \mathrm{gpm}$

+ sCVC area $=584 \mathrm{ft}^{2}$

$+\Delta t_{C w}=\frac{Q}{m C_{p}}=\frac{938400}{100 \star 500 \star 1}=18.8^{\circ} \mathrm{C}$

$$
\Rightarrow t_{e}=28.8^{\circ} \mathrm{C}
$$

$+\Delta T_{\operatorname{lm}}=\frac{(72-10)-(72-28.8)}{\ln \frac{72-10}{72-28.8}}=52.03^{\circ} \mathrm{C}$

+ Uscve reqd $=\frac{Q}{A \Delta T_{1 m}}=\frac{938400}{584 \star 52.03}=53.7 \frac{\mathrm{PCU}}{\mathrm{hr}-\mathrm{ft}^{2}-{ }^{\circ} \mathrm{C}}$

Again, this condenser should have no problem handling the full boilup.

\section{Ounlity Asaurance}

Heat transfer coefficients are derived from PHEF operating data stored by the Vantage data collection system running on the VAX computer located in 679-T. The heat transfer calculations were peer reviewed by $D$. P. Lambert.

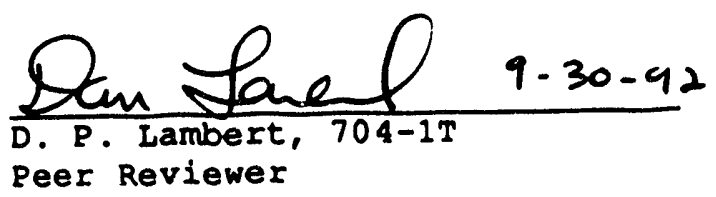




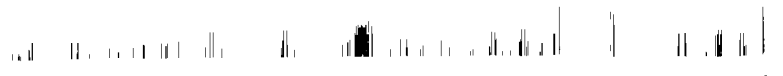
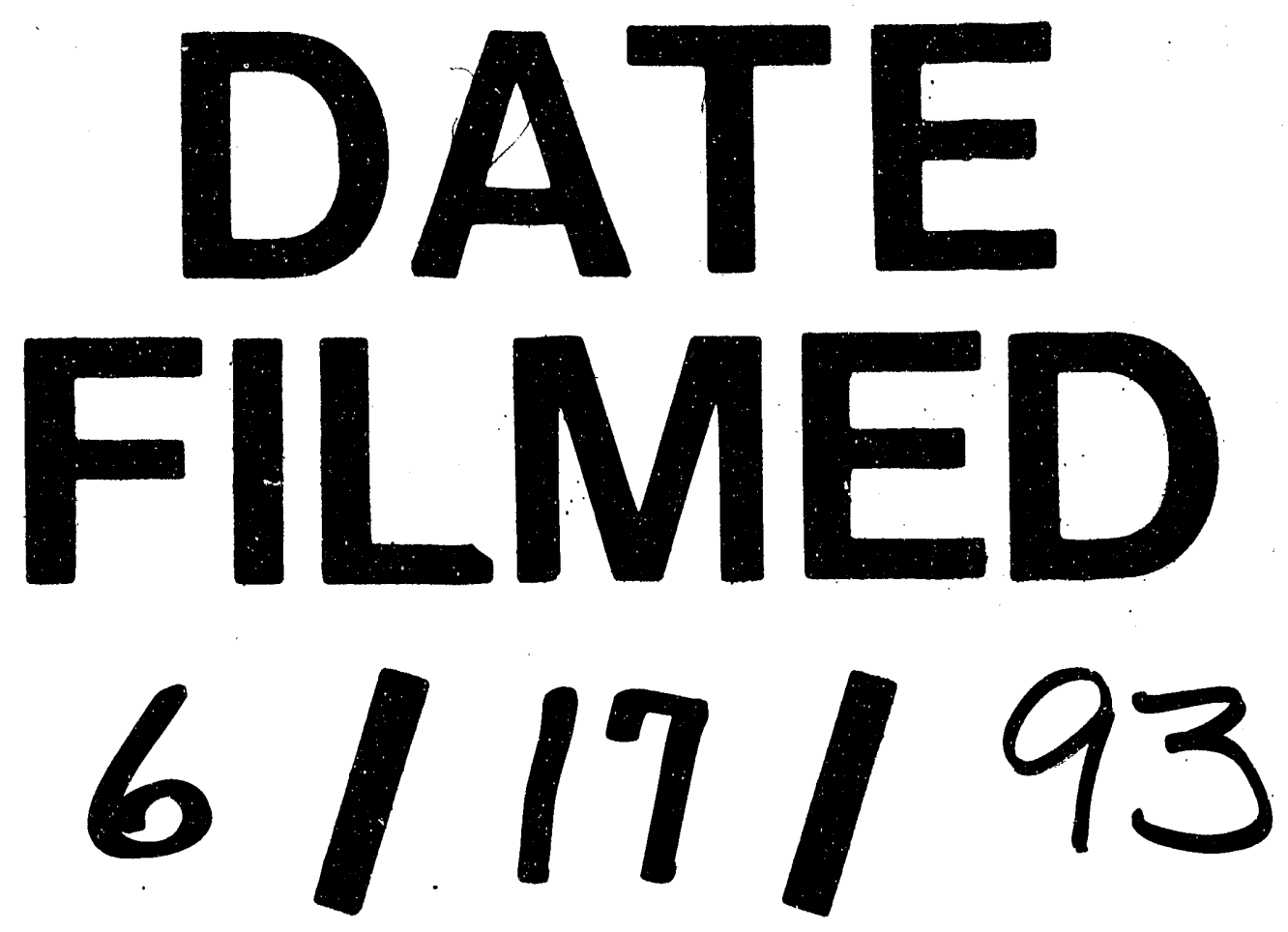
